\title{
Globalization and African Culture: The Nigerian Experience
}

Asenge, Emmanuel Lubem

Department of Business Management, Benue State University, Makurdi-Nigeria

DOI: $10.36347 /$ sjebm.2020.v07i04.004

| Received: 06.04.2020 | Accepted: 14.04.2020 | Published: 28.04.2020

*Corresponding author: Asenge, Emmanuel Lubem

Abstract

Original Research Article

Globalization involves the process of stretching or extending and intensifying human activities, relations and networks across the globe, and it has produced complex interactions between different cultures. Different cultural values are practiced in Nigeria through the process of globalization. This study investigates the effect of globalization on African culture with particular reference to Nigeria. The study specifically examines the effect of globalization on the value system in Nigeria and the effect of globalization on changes in language in Nigeria. A sample of 350 was selected for the study through purposive sampling technique. A pilot test was carried out in the study to determine the reliability of the instrument. Data collected for the study were tested using simple linear regression analysis with the aid of the Statistical Package for Social Sciences (SPSS 23). The findings of the study revealed that globalization has a significant effect on the value system in Nigeria. The research also indicates a significant effect of globalization on changes in language in Nigeria. The study concludes that value systems ad languages in Nigeria have been gradually eroded through the process of globalization. The study recommends that there is an urgent need for African leaders to revive African culture through their respective ministries, agencies, and department, and curriculum developers should ensure that local languages are taught at all levels of the educational system in Nigeria.

Keywords: Globalization, Culture, Value System, Language.

Copyright @ 2020: This is an open-access article distributed under the terms of the Creative Commons Attribution license which permits unrestricted use, distribution, and reproduction in any medium for non-commercial use (NonCommercial, or CC-BY-NC) provided the original author and source are credited.

\section{INTRODUCTION}

The world is now becoming a global village, where people, including those in the most remote parts of the world are increasingly interconnected that eliminates distance barriers which earlier existed. Globalization portrays a world that is borderless, which ensures the interconnectedness of nations from hundreds and thousands of kilometers without minding the geographical distance. The coming together of political, social, cultural, economic, and religious factors driven by the development of information and communication technologies is created by globalization. It has increased interdependence and interconnectivity between different countries and cultures around the globe. Globalization refers to an expanding scale with growing magnitude with deepening and expanding the impact of transcontinental flows and patterns of interaction [1]. Globalization today, imposes nonindigenous cultural uniformity among nations. This cultural imperialism under the pretext of globalization is imposing western values on unsuspected poor African people to improve their economic prosperity. American values and products are regular features and peddled through their films, television programs, seductive commercials, music, and other culturally demeaning programs foreign to African culture but slowly penetrating their culture and invading their tradition $[2,3]$.

Globalization has emerged as a result of a series of developments internal to social theory, notably the reaction against earlier perspectives such as modernization theory. Ritzer [4] asserts that although economic and political issues are of great importance, it is cultural issues and cultural theories that attract the most attention in society. Culture is a learned set of shared interpretations about beliefs, values, and norms which affect the behaviors of a relatively large group of people [5]. Culture is not a genetically inherited trait of human beings, but rather, is learned. Cultural globalization entails the infiltration of foreign cultures into African culture, norms, values, and alteration of African social structure [6]. Cultural globalization has created unparalleled inequity throughout Africa, affected the behavior of people in numerous ways, and forced many people to assume a lifestyle of selfinterest, selfishness, individualism and made people develop a psychopathic devotion and appetite for foreign films, goods, foods, way of life, music, attitude and behavior which has always been foreign to African community [5]. 
Studies have shown that the African continent has not benefited from the process of globalization and that it has exacerbated the problem of poverty in the continent. They attributed the underdevelopment in Africa majorly to globalization $[3,7,8]$. The need for a cultural renaissance of the African experience is a product of the current cultural evolution engendered by the cultural contacts of Africans with the west in historical moments of colonialism and globalization. This cultural contact has brought about forced acculturation that has left the rich cultural heritage of Africa in a precarious condition of imminent extinction. The culture of the developed economy has taken over the local culture, and many Nigerians prefer the cultural practices of the developed countries. Globalization has affected the cultural values and language system in African countries, including Nigeria. The harmful effects of globalization seem to be more conspicuous and alarming among the youths in Nigeria and the peculiar Nigerian cultural values, like languages and dressing, are being eroded by the modern culture brought about by globalization. The researcher is therefore motivated to investigate the effect of globalization on African culture with particular reference to Nigeria.

\section{Objectives of the study}

The broad aim of the study is to examine the effect of globalization on African culture. The study specifically examines the:

- effect of globalization on changes in the value system in Nigeria

- $\quad$ effect of globalization on changes in language in Nigeria

\section{Research Hypotheses}

The following hypotheses were formulated in a null form to achieve objectives of the study:

$\mathrm{HO}_{1}$ : Globalization has no significant effect on changes in the value system in Nigeria

$\mathrm{H}_{2}$ : Globalization has no significant effect on changes in language in Nigeria

\section{LITERATURE REVIEW}

There has been increasing concern over the years by scholars and writers on how the world is being compressed into a single space now referred to as 'a global village.' Countries at various stages of development are increasingly forced to take account of an ever-expanding interconnection of socio-cultural issues and economies in the management of their national affairs. Globalization is a critical tool for cultural homogeneity and end to cultural diversity in the world.

\section{Concept of Globalization}

Globalization has been variously defined by many scholars. Globalization is the multifaceted process that involves the emergence of global financial markets exchanging vast sums ever with the increasing speed of movement of global actors like multinational corporations, massive media empires whose powers may exceed that of some governments [9]. Stilgizt [10] defined globalization as an increased speed of development in which modern technologies, production techniques, organizations, consumption patterns, and worldviews are spreading across the globe. He emphasized that globalization is a far-reaching sociocultural process than a mere economic trend.

Globalization is defined by Nsibami [11] as a process of advancement and increase in interaction among the world's countries and people facilitated by progressive technological changes in locomotion, communication, political and military power, knowledge, and skills, as well as interfacing of cultural values, systems, and practices. He further explains that globalization is not a value-free, innocent, selfdetermining process. This definition is supported by Kwame [12], who looked globalization as a process of linking regions, and nations of the world which is facilitated by information flow (communication) inducing changes in the pre-existing socio-cultural, political, economic and educational structures and systems of nations and peoples.

Globalization is the intensification of crossborder trade and increased financial and foreign direct investment flows among nations, promoted by rapid advances in the liberalization of communication and information technology [6]. Obioha [13] asserts that globalization is the international, socio-politicoeconomic, and cultural permeation process facilitated by policies of the government, private corporations, international agencies and civil society organizations. Globalization creates a sturdy link and interconnectedness within international agencies, communities, and associations that vindicate harmony and inter-alia relations in public policies and private sector management within the global arena. It consolidates uniformity in governing the international community. The above definitions suggest that the trend of globalization has created an integration of the divergent systems, nations, and institutions around the globe, which has brought about political, socio-cultural, educational, and economic changes.

\section{Concept of Culture}

Culture is the total way of people's life that includes customs and costumes, manners and mannerism, ideas and ideology, art, beliefs, and all sorts of things that integrate people as members of the society. The concept of culture consists of the values the members of a given group hold, the norms they follow, and the material goods they create. It refers to the way of life of the individual member of groups within society, how they dress, their religious ceremonies, and leisure pursuit [14]. Culture differentiates one community with the other, even within the African continent. It is a complex whole, 
including knowledge, beliefs, art, morals, laws, customs, and any other capabilities and habits created by men who are members of society. However, culture makes a group of people relate to each other through persistent relationships. It also makes a large social group share the scarce geographical or virtual territory, subject to the same political authority and dominant cultural expectations [15].

The above definition justifies how one community differs from the other due to their different cultural orientations. For instance, the Swahilis from the east African states (Kenya, Djibouti, Tanzania, Uganda, and Zanzibar) differ in their culture with the Babers and Arabs in the North African states of Algeria, Libya, Mauritania, Morocco, Egypt, and Tunisia, while the culture of Hausa/Fulani of the West African states of Northern Nigeria, Ghana, Niger, Cameroon, Chad, and Gambia were also different from the Kwazulu of the South African region. In other words, the Malays of Malaysia, Indonesia, Brunei and Singapore are different from the Chinese, Indians, and Thais of China, India, and Thailand, even if they are staying in Malaysia or Indonesia. In Nigeria, different cultural values are associated with various cultures. For example, the cultural orientation of the Hausa/Fulanis, Yorubas, Igbos, Tivs, Ijaws, Nupes, amongst others, is different.

In the process of international interactions, there is an interaction of cultures, and thus a borrowing and diffusion of cultures amongst nations [13]. Impliedly, globalization has negative impacts on the indigenous culture that would make the people behave outside their traditional orientation, customs, and beliefs. This scenario might precipitate the ascendancy of western culture on the domestic customs of the local African people.

\section{Effect of Globalization on the Value System}

Value denotes the degree of importance of something or action, to determine what actions are best to do or what way is best to live (normative ethics) or to describe the significance of different events. Value systems are the set of values according to which people, a society, or organization regulate their behavior. Value systems are proscriptive and prescriptive beliefs; they affect the ethical behavior of a person or are the basis of their deliberate activities. Often primary values are strong, and secondary values are suitable for changes. Today, the rapid and aggressive spread of market economies and communication technologies under the influence of western multinationals brings new impediments to local cultures and values, particularly in Africa and non-western societies at large. Nigerians, in particular are now cultivating the materialistic and individualistic habits and values previously associated with western culture. The culture of individualism is fast eroding the values and ideals of the extended family system, which Nigerians are known for [13].
Oni [14] views Nigerian cultures as being weak when compared with western culture and consequently, bound to lose in a battle against western culture. He asserts that the situation in Africa today is so pathetic as a result of the gradual admittance of western culture at the detriment of our own culture. Africa has consequently changed from a land of culture, nature of tradition and rural setting where the cockcrow signals the dawn of a new day. The harmful impact of globalization seems to be more conspicuous and alarming among youths. Oni [14] observes that Nigerian youths are rapidly losing touch with cultural values and that this is seen in the alien culture which they portray; their bizarre dressing, dancing, and language and so on, which invariably affect other aspects of social life.

Ogunjimi and $\mathrm{Na}$ 'Allah [16] argue that Nigerian cultural values such as greeting norms, cuisine, appearance and dress, custom, occupations, and cultural components are giving way to acculturation "the suppression and subjugation of African culture," a tragic phenomenon that is fast destroying the original cultural complexion of not only the younger generation but even the adults. They further explain that indigenous tradition and tribal cultures are being displaced and booted out of existence by Western media products that continue to bombard with commercials, especially from Americans and exposing people to lifestyles that are not easily attainable through a makebelief situation. In Nigeria due to the impact of globalization on cultural norms, socialization processes, and values are affected. For instance, some parents are no longer frowning at what the youths put on. Regrettably, the traditional pattern of subordinating when greeting an elder has changed.

\section{Effect of Globalization on Changes in Language}

Language is a cultural system; individual languages may classify objects and ideas in wholly different fashions because every person belongs to his or her cultural language for communication within the environment. Language shapes our distinctive ways of being in the world. It is a carrier of people's identity, the vehicle of a definite way of seeing things, experiencing and feeling, determinant of particular outlooks on life [13].

Globalization has transformed Africans to become Anglophones, Francophones, and Lexiphones'. It has made them speak in English, French, or Portuguese. This appalling dominance of western languages has relegated the indigenous languages in Africa, whereby some Africans hardly speak or feel shy to speak their mother tongue but are more comfortable with the European languages. This is a Eurocentric mission against the African languages that may lead to the extinction or decline of some languages in Africa, including the major ones. Ogunjimi and Na'Allah [16] argue that the peculiar Nigerian cultural values, like 
languages, are being eroded by the pop culture brought about by globalization.

Today, foreign languages have generated momentum as the international lingua franca in international communication, which is detrimental to African languages. If a lost language is a lost culture and a lost culture is an invaluable knowledge lost, then efforts should be made to develop a common languageWA-ZO-BIA (which is a combination of the languages of the three main ethnic groups in Nigeria. However, the experience in Nigeria today is a gradual phasing away of the traditional languages and the enthronement of the English language in every facet of lives. The English language has become the official language of Nigeria both in private and public life. Today, it is rare to have students who willingly enroll to study any of the local/indigenous languages in the higher institutions unless such courses are offered to them against their choices. Those who see themselves studying them are not proud, and scholarships and other forms of incentives are never given to them; rather, the government spends millions of naira on incentives to those studying foreign languages such as English, French, German, or science subjects.

Consequently, educational qualification in any of the local languages has become of less value than a qualification in the colonial languages because of the influence the imperial countries exert over Africa in general, and Nigeria in particular as a result of their science-supported civilization [5]. Colonialism eroded the place of African languages in African economies by granting the highest prestige value to school education in colonial languages. Today, the use of English has always been an imperative aspect of the official communication medium in Nigeria. Nigerians use and read books written in a foreign language faster and more fluently than those written in local languages. Cultural globalization has impacted on the number of Movies produced by Nigeria Nollywood; movies produced in English are much more than those performed and produced in other Nigerian local languages. Tuhus-Dubrow [17] explain that a language is considered endangered when it is no longer spoken by children, moribund by only a handful of the elderly speaker and left to extinct when it is no longer spoken.

\section{METHODOLOGY}

The study adopted a survey design. This study is concerned with the collection of data for the purpose of describing and interpreting existing conditions, prevailing practices, beliefs, attitudes, on-going processes, effects that are felt, or trends that are developing. The design was adopted for the study because it helped in describing the pertinent aspects of the phenomena under consideration and provided detailed information about each relevant variable. The study collects primary data through a self-administered questionnaire and interviews. The target population for this study includes over 1 million adult Nigerians, and a sample of 350 was purposively selected. A simple random sampling technique was used in the selection of the participants since every member of the population has an equal chance of being selected for the study. A pilot test was conducted on the instrument to ensure consistency of measurement items, and the result of the Cronbach Alpha showed that all the variables were reliable and consistent with being used for this study. Data collected were coded and analyzed using the Statistical Package for Social Sciences (SPSS 23). Simple linear regression analysis was used to determine the effect of the independent variable on the dependent variable. Formulated hypotheses were tested at a $5 \%$ level of significance.

\section{RESULTS}

The result of the simple linear regression analysis was presented in Tables 1 and 2, respectively, and formulated hypotheses were tested accordingly.

Table-1: Regression Coefficients

\begin{tabular}{|c|c|c|c|c|c|}
\hline & & $\begin{array}{l}\text { Unstandardized } \\
\text { Coefficients }\end{array}$ & & $\begin{array}{l}\text { Standardized } \\
\text { Coefficients }\end{array}$ & \\
\hline & B & Std. Error & Beta & $\mathrm{t}$ & Sig. \\
\hline Constant & 2.528 & .261 & & 9.671 & .000 \\
\hline Globalization & .366 & .066 & .440 & 5.559 & .000 \\
\hline \multicolumn{6}{|c|}{$\begin{array}{lll}\mathbf{R} & = & .640 \\
\text { R Square } & = & .493 \\
\text { Adj. R Square } & = & .487 \\
\text { F-Statistics } & = & \mathbf{3 0 . 9 0 1} \\
\text { Sio } & & \end{array}$} \\
\hline
\end{tabular}

a. Dependent Variable: Value System

Source: Field Survey, 2020.

The result in Table 1 shows that the coefficient of determination ( $\mathrm{R}$ square) explains the variation in the dependent variable due to changes in the independent variable. The $\mathrm{R}$ square value of
0.493 indicates that there was a $49.3 \%$ variation in value system due to changes in globalization at a 95\% confidence interval. Also, the value of $\mathrm{R}(0.640)$ from the Table shows a positive relationship between 
the study variables. The result of ANOVA statistics indicates that the processed data, which is the population parameters, had a significance level of 0.000 , which shows that the model was statistically significant $(\mathrm{F}=30.901 ; \mathrm{P}=.000)$. The regression coefficient reveals that a unit change in globalization would affect the value system by $36.6 \%$, and the $\mathrm{p}$ value (.000) was less than 0.05 . The null hypothesis was rejected and we conclude that globalization has a significant effect on changes in value systems in Nigeria.

Table-2: Regression Coefficients

\begin{tabular}{|c|c|c|c|c|c|}
\hline & & $\begin{array}{l}\text { Unstandardized } \\
\text { Coefficients }\end{array}$ & & $\begin{array}{l}\text { Standardized } \\
\text { Coefficients }\end{array}$ & \\
\hline & $\mathrm{B}$ & Std. Error & Beta & $\mathrm{T}$ & Sig. \\
\hline Constant & 1.786 & .255 & & 7.007 & .000 \\
\hline Globalization & .489 & .064 & .558 & 7.636 & .000 \\
\hline & $\begin{array}{l}\text { A } \\
\mathbf{F} \\
\mathbf{F}\end{array}$ & $\begin{array}{lc} & =.558 \\
\text { Square } & = \\
\text { dj. R Square } & = \\
\text { Statistics } & = \\
\text { g. } \quad & .000\end{array}$ & $\begin{array}{l}.311 \\
.306 \\
\mathbf{5 8 . 3 1 1}\end{array}$ & & \\
\hline
\end{tabular}

a. Dependent Variable: Language

Source: Field Survey, 2020.

The result in Table 2 shows that the coefficient of determination ( $\mathrm{R}$ square) explains the variation in the dependent variable due to changes in the independent variable. The $\mathrm{R}$ square value of 0.311 implies that there was a $31.1 \%$ variation in language due to the effect of globalization at a $95 \%$ confidence interval. Also, the value of R (0.311) from the Table shows positive relationship between the study variables. The result of the ANOVA statistics also indicates that the processed data had a significance level of 0.000 , indicating that the model was statistically significant $(\mathrm{F}=58.311 ; \mathrm{P}=.000)$. The regression coefficient revealed that a unit change in globalization would affect changes in language by $48.9 \%$, and the p-value (.000) was less than 0.05. The null hypothesis was rejected, and we conclude that globalization has a significant effect on changes in language in Nigeria.

\section{DISCUSSION}

The findings of the study established a significant effect of globalization on the value system in Nigeria. It shows that Nigerian cultural values such as greeting norms, dressing, marriage system, eating habits, and occupations are gradually eroded because of globalization. This result is in agreement with Obioha [13], who averred that Nigerians are now cultivating the materialistic and individualistic habits and values previously associated with western culture, and such culture is fast eroding the values and ideals of the extended family system in Nigeria. Oni [14] explained that the negative effect of globalization is more conspicuous and alarming among the youths in Nigeria. This is supported by Ogunjimi and Na'Allah [16], who argued that Nigerian cultural values have been suppressed and subjugated by Western culture. The implication of the finding to the study implies that the African cultural values such as dressing and greeting patterns had been allowed to erode for a long time through the process of globalization.

The result collected from data analysis also indicated that globalization has a significant effect on changes in language in Nigeria. Findings showed that Nigerian languages are gradually going into extinction because of globalization. This result is supported by previous studies that showed the effect of globalization on changes in language in Africa. Ogunjimi and $\mathrm{Na}$ 'Allah [16], in their research, established that the peculiar Nigerian cultural values, like languages, are being eroded by the modern culture brought about by globalization. Tuhus-Dubrow [17] also showed the negative effect of globalization on language extinction in Africa. The implication of the finding to this study is that local languages have been abandoned in Nigeria, and this has a negative effect on our culture.

\section{CONCLUSION AND RECOMMENDATIONS}

The study examines the effect of globalization on African culture with a particular focus on Nigeria. The research indicates that the integration of Africa through the conduit of globalization has already eroded the sovereign power of Africa, infused African culture, and turned the Africans to become vulnerable to western ideology. The continuous dependence on western culture has posed an enormous set back to the Africans in building their nation-states within the purview of their traditions, culture, and belief. The study concludes that globalization has impacted negatively on Nigerian culture by encouraging Nigerians in copying wrong foreign cultures. The study also concludes that value systems, and languages in Nigeria have been increasingly wrinkled through the process of globalization. Based on findings of the study and conclusion drawn above, the study recommends that there is an urgent need for African leaders to revive 
African culture via their respective ministries, agencies, and departments. Festivities like Festival of Arts and Culture (FESTAC) should be organized promptly to instill cultural consciousness in the minds of African youths and the subsequent generation. Seminars, workshops, and conferences should be arranged in Nigeria to enlighten the citizens about cultural values. The paper also recommends that curriculum developers should ensure that local languages are taught at all levels of the educational system in Nigeria. Further studies could be carried out on the effect of globalization on economy, education, and religion growth in Africa. Also, the effect if other aspects of globalization, such as economic and political globalization in Africa could serve as areas of research by future researchers.

\section{ACKNOWLEDGMENT}

I sincerely appreciate the contribution of Prof. S.E. Nongo, towards the success of this research. Also, I appreciate respondents, who provided relevant information that helped in the successful completion of this work.

\section{REFERENCES}

1. Held D, McGrew A. The great globalization debate: An introduction. The global transformations reader. 2003 Aug 1;1(7).

2. Ajayi SI. Sub-saharan Africa: The myth and the reality. Globalization and equity: Perspectives from the developing world. 2005:67-97.

3. Adei S. Impact of globalisation on management the African perspective. Management in Nigeria. 2004;39:40.

4. Ritzer G, editor. The Blackwell companion to major classical social theorists. John Wiley \& Sons; 2008 Apr 15.

5. Daramola I, Oyinade B. Impact of cultural globalization on African: the role of western media.
International Journal of education \& research. 2015;3(3):2201-6740.

6. Akande W. The drawbacks of cultural globalization. Yellow Times. 2002 Nov;10.

7. Amiuwu LEA. Globalisation: The Human Resource Challenge. Management in Nigeria.2004; 39/40, 2/1

8. Aluko MA, Akinola GO, Sola F. Globalization and the manufacturing sector: A study of selected textile firms in Nigeria. Journal of social sciences. 2004 Sep 1;9(2):119-30.

9. Armstrong D, Lloyd L, Redmond J, Armstrong D. International organisation in world politics. Basingstoke/New York: Palgrave Macmillan; 2004.

10. Stiglitz JE. Globalization and its discontents. New York: Penguin Books;2002.

11. Nsibambi A. The effects of globalization on the state in Africa: Harnessing the benefits and minimizing the costs. Paper presented at UN general assembly, second committee; Panel discussion on globalization and the state; 2001.

12. Kwame Y. The Impact of globalization on African culture. University of Southern Denmark; 2007.

13. Obioha UP. Globalization and the future of African culture. Philosophical Papers Reviews.2010; 2(1): $1-8$.

14. Oni AA. Globalization and Its Implication on African Culture and Development: Challenges for Education. International Journal of African and African American Studies.2005; 4(2)

15. Weber EU and Hsee C. Cross-cultural differences in risk perception, but cross cultural; 1998.

16. Ogunjimi $\mathrm{B}$ and $\mathrm{Na}$ 'Allah $\mathrm{A}$. Introduction to African Oral Literature and Performance. Trenton, NJ: Africa World Press, Inc.2005.

17. Tuhus-Dubrow R. World's Languages Are Fast Disappearing Global policy forum. Internet document; 2004. 